\title{
Exploration of Teaching Method of College English Translation based on the Situated Cognition
}

\author{
Xiaofang Tian \\ Tianjin Vocational Institute, Tianjin, 300410, China
}

\begin{abstract}
Keywords: Situated Cognition; College English Translation Teaching; Application Research; Current problems; Solutions

Abstract. The theory of Situated Cognition holds that:" Knowledge and activity are in a system in which they are concomitant and inseparable." Based on this theory, three effective teaching strategies came into being - cognitive apprenticeship, interactive teaching and anchored instruction. The three teaching strategies can play a significant role in the reform of college teaching, and if applied to the college English translation teaching, they can definitely achieve good results. However, the core of application is to summarize the current drawbacks of the college English translation teaching and find out the corresponding solutions. Improvements should be made in terms of talent training mode, curriculum and teaching model of college English translation. This paper analyzed these aspects briefly and offered strategies to solve relevant problems.
\end{abstract}

\section{Introduction}

With the rapid development of China's economy and the rising international status, the exchanges of all aspects like politics, culture and economic are becoming ever more frequent between China and other countries, this social state has resulted in the shortage of translators for each industry now in our country. This phenomenon also provided a good opportunity for the development of college English translation teaching and translation talents training. However, opportunities and challenges always coexist. Such a good opportunity also brings college English translation challenges, which is the education reform. We can see clearly from the current situation that great deals of problems now exist in the college English translation teaching. The proposal of situated cognition, however, brings hope to the educators of college English. This theory is thought by researcher to be able to bring meaningful learning opportunities to learners, and can facilitate learners to put expertise into real life scenarios. Moreover, the situated cognition has much value in translation teaching and translation talents cultivation.

\section{Overview of situated cognition}

\section{The definition of situated cognition}

Situated cognition, proposed by the west at the end of last century, is an educational theory that integrates constructivism with anthropology. A research team composed by Brown America et al, after making analysis and research of the psychology of learners, pointed it out that: people's knowledge and activity are inseparable. Instead of being a supplementary means in people's learning, activity is a key integral part in learning. According to this theory, students must do relevant activities to coordinate the learning of new knowledge; teachers should also pay more attention to the scene in which the students conduct learning activities in the teaching process. In addition to this, anthropology maintains a similar view with the psychology. Wenger and Lave think that human's cognition is build up on activities and scenes, they therefore call the process of learning in the scene as "legitimate peripheral participation", which emphasizes the social participation between teaching and learning and the function of interaction.

Situated cognition integrated the two opinions mentioned above. It maintains that knowledge and activity are inseparable. Learning is a process that learners acquire knowledge and effective ways to solve problems in real situations; it is the interaction between the learners and the real situations. Learners can build up a complete system of new knowledge in this way.

Characteristics of situated cognition 
Situated cognition regards knowledge as the branch of scenes and that education cannot be separated with activity. Knowledge is what human beings discovered and accumulated in the practice; therefore, knowledge and activity are closely related. In other words, knowledge is the experiences accumulated in human's life, and education is a good route to transmit and enrich human's experience. Education is also a process that learners cultivate their comprehensive moral quality and acquire knowledge and skills through the interaction and interplay with other people. Thus, we can say from an objective perspective that: "Education is the accumulation of life experience and the process to grow."

In addition to this, situated cognition also believes that learning is a participant process. That being the case, learning and social life are inseparably intertwined. Learning is an activity that needs to be done through practice. Only the learners acquire knowledge through observation, imitation and hands-on operation, can they turn the knowledge they can't understand into their own knowledge accumulation. Situated cognition also emphasize that learning is closely related to social practice and even social life.

\section{Teaching model under the guidance of situated cognition}

The proposal of situated cognition aroused a vast number of scholars and educators to explore and ponder, three teaching model thus came into being under the guidance of this theory. Our country, however, didn't know too much about these teaching models due to geographic distance. Until the beginning of 21th century, the development of network technology made it possible for the three teaching models to integrate with modern technology and further enrich themselves.

\section{Cognitive apprenticeship}

Cognitive apprenticeship means to enable students to participate in the practices through the interaction with the society. The interaction includes various cooperation and contacts of social nature both in and out of school and the construction system of knowledge of social nature. This teaching model is much similar to the craft apprenticeship system. Application of cognitive apprenticeship requires the teachers to play the role of master worker and tutor, which is to enable students to understand knowledge and grasp skills by demonstration and guidance.

\section{Anchored instruction}

Anchored instruction refers to that teachers set the questions to be explained in a situation. It is a teaching model that the teachers enable the students to learn through setting the situation, finding out the questions, solving the questions and evaluating the results. The problem of this teaching model is that the teachers must set the questions in an accurate and appropriate way and give timely inspiration and guidance to the students during the teaching.

\section{Interactive teaching}

Interactive teaching is a teaching method that enables students to acquire knowledge through the joint cooperation with teachers. It aims to create good cooperation and exchange between teachers and students and bring out the independent learning capacity and initiative of students toward learning.

Favorable results of the application of the situated cognition to college English translation teaching

\section{Useful to promote the reform and innovation of English translation teaching model}

At present, a widespread problem in the talent training of English translators is that the colleges emphasize too much on the specialized theory knowledge and ignore the practices. Moreover, many aspects like the construction of teacher staff, infrastructure and training base are now under the process of perfection. Take the textbook of college English translation teaching for example, the contents of which is quite boastful. It has no much use in practice and is out of touch with real life. Many students find textbooks of little use in their learning. As for the teaching mode, many English translation teachers in colleges still follow the traditional teaching method, which is to take teachers as focus and cram students the knowledge. There is not any interaction and communication between teachers and students. This traditional teaching method restrains students' activity and motility to a great extent. 
Situated cognition is a theory that attaches great importance to the cultivation of students' practical translation skills. The theory itself can favorably promote the reform and innovation of the talent training mode of colleges and offer new trends for the reform and innovation of curriculum and relevant teaching strategies to follow. These changes are conducive to the cultivation of translation talents and allowing students to become the comprehensive talents of high comprehensive and practical skills, which is rightly what the society needs.

Useful to motivate students' interest in learning, and can make the classroom atmosphere more relaxed

A virtually real communication scenario can be made for students if teachers integrate situated cognition with multimedia technology. In such a scenario, students can participate in the practice independently and actively around the content centre set by teachers. Students can also find ways to solve problems and accumulate new experience in the interactive process and finally establish and perfect their own knowledge system. The new knowledge system takes students as the core and problem solving as ultimate purpose. It can guide students to learn through interaction and cooperation. If situated cognition were applied in the translation teaching, the focus of which should no longer be the exam results, but rather the practical translation ability of students, which is the solid foundation to the success of relevant career. In this way, a very equal partnership will come into being between students and teachers, the atmosphere of class will become relaxed and happy. Students' enthusiasm for learning will increase and the efficiency of classroom teaching will be greatly enhanced.

\section{Application strategies of situated cognition in college English translation teaching}

\section{Reform the traditional translation teaching mode}

Situated translation believes that cognition is a part of situation. Suppose the translation talent training mode were changed in accordance with this theory, we shall firstly work out a situation similar to real-life in line with the need of translators in various occupations, allowing students to accept necessary education and training in such a situation. In carrying through efficient English translation teaching, teachers must fully realize the importance of simulation and practice, and try hard to expand the areas in which students can practice. In this way, college English translation teaching based on situated cognition can truly cultivate application-oriented English translation talents of high-quality and high-performance.

\section{Appropriate adjustments to the course and teaching content in line with the requirements of situated cognition}

According to the requirements of situated cognition, the colleges shall take full account the matching degree between the specialty orientation of students and the course content in designing the content of college English translation course, and increase the proportion of practice courses. The teaching shall focus on the cultivation of student's practical translation skills. Meanwhile, colleges shall develop relevant supplementary courses according to the cultivation requirements of English translation talents in different colleges. Thus, students can both posses solid knowledge base and complete knowledge structure. Colleges shall also try all means to improve students' comprehensive strength. Students can't study in a real situation only if the situated cognition were integrated in the college English translation teaching. Should that be the case, the learning initiative of students can be fully motivated and the social consciousness of them can get full developed.

\section{Conclusion}

Colleges are the main base to train translation talents of high-quality and high-level, the educators of colleges, therefore, shoulder the great responsibility to train the translation talents, especially the technical translation talents in our country. The prospect is nevertheless worrisome in light of the current situation of college English translation teaching, lots of existing malpractices have hindered the training of English translation talents in the new age. Therefore, college teachers shall drive forward the reform of the content of college English teaching and improve the 
comprehensive quality and translation skills with the employment of situated cognition. Only in this way can the colleges train translation talents of high quality for the society.

\section{Reference:}

(1) Wang Xue, "Situated Cognition and College English Translation Teaching” [J], Education Exploration, 2012(12)

(2) Chen Shan, "Reform and Design of the Course of English Major Curriculum in Colleges" [D], Shanghai International Studies University, 2012 (04)

(3) Fu Zhenjie, "Translation Teaching Research for English Majors of Institutions of Higher Learning” [D], Shandong University, 2010(12).

(4) Zhang Ruie, "Construction of the Subjects' Communication System in Translation Teaching for English Majors” [D], Shanghai International Studies University, 2012 (05).

(5) Zhang Xia, "Research about Countermeasures to Improve the Efficiency of College English Translation Teaching”[J].Overseas English, 2010 (09).

(6) Xu Jun, "A Corpus-based Study on the Current Status of the English Textbooks of Translation and the Teaching of Translation”[J], Computer-assisted Foreign Language Education, 2008（09）.

(7) Jiang Xiaoli, “On Translation Teaching in College English from an Empirical perspective” [J], Journal of Hefei University of Technology (Social Sciences), 2009(04)

(8) Xuan Yimei, "Discussion about College English Translation Teaching” [J], Fujian Tribune (A Economics \& Sociology Monthly), 2009 (08).

(9) Deng Yan, Liu Lianfang, "Research about the Integrated Innovation of English Translation Teaching mode" [J], Journal of Hunan Agricultural University (Social Science. Quality-oriented education research), 2008 (09)

(10) Li Li, "Research about the New Teaching Mode of Translation-“Imitate" the Practical Application of Translation Teaching Mode” [J], Kao Shi Zhou Kan ,2013(08) 